\title{
Design and synthesis of cationic antibacterial peptide based on Leucrocin I sequence, antibacterial peptide from crocodile (Crocodylus siamensis) white blood cell extracts
}

\begin{abstract}
Nualyai Yaraksa ${ }^{1}$, Thitiporn Anunthawan ${ }^{1}$, Tinnakorn Theansungnoen ${ }^{1}$, Sakda Daduang ${ }^{1}$, Tomohiro Araki ${ }^{2}$, Apisak Dhiravisit ${ }^{3}$ and Sompong Thammasirirak ${ }^{1}$

Leucrocin I is an antibacterial peptide isolated from crocodile (Crocodylus siamensis) white blood cell extracts. Based on Leucrocin I sequence, cationic peptide, NY15, was designed, synthesized and evaluated for antibacterial activity against Bacillus sphaericus TISTR 678, Bacillus megaterium (clinical isolate), Vibrio cholerae (clinical isolate), Salmonella typhi (clinical isolate), Salmonella typhi ATCC 5784 and Escherichia coli 0157:H7. The efficacy of the peptide made from all L-amino acids was also compared with all D-amino acids. The peptide made from all D-amino acids was more active than the corresponding L-enantiomer. In our detailed study, the interaction between peptides and the cell membrane of Vibrio cholerae as part of their killing mechanism was studied by fluorescence and electron microscopy. The results show that the membrane was the target of action of the peptides. Finally, the cytotoxicity assays revealed that both L-NY15 and D-NY15 peptides are non-toxic to mammalian cells at bacteriolytic concentrations.
\end{abstract}

The Journal of Antibiotics (2014) 67, 205-212; doi:10.1038/ja.2013.114; published online 6 November 2013

Keywords: antibacterial peptide; cationic antibacterial peptide; killing mechanism; scanning electron microscopy; transmission electron microscopy

\section{INTRODUCTION}

Antimicrobial peptides (AMPs) have an important role in the innate immune system of most living organisms. These peptides are small, cationic and amphipathic molecules. Currently, >900 AMPs have been isolated from a wide variety of organisms. ${ }^{1}$ Evidence has suggested that AMPs are of greatest potential to represent a new class of antibiotics. ${ }^{2,3}$ Cationic AMPs belong to the innate immune system and host defense mechanism of a wide range of living organisms. ${ }^{4,5}$ Many AMPs appear to act via specific, but not receptor-mediated, permeabilization of microbial membranes and have selective targets in their specificity of killing. ${ }^{6}$ All of them cause lysis by two-step mechanisms, which consists of (i) binding to a negatively charged membrane with a cationic nature and (ii) permeabilization of the microbial membrane. ${ }^{7}$ Nevertheless, these peptides use many structures and mechanisms to destroy microorganisms, including binding to an intracellular target such as DNA, RNA and/or protein, and interacting with enzymes causing inhibition of metabolic processes. ${ }^{8}$ These properties confer considerable potential for the development of these agents as novel therapeutic agents to overcome the resistance problem. ${ }^{9}$
In a previous study, Pata et al. ${ }^{10}$ purified Leucrocin I, II, III and IV from crocodile (Crocodylus siamensis) white blood cell extracts. Leucrocin I exhibits strong antibacterial activity toward Staphylococcus epidermidis, Salmonella typhi and Vibrio cholerae but the MIC values of synthetic peptide Leucrocin I seem higher than native peptide. Hence, in this study, we have taken Leucrocin I peptide as sequence template for the design and synthesis the novel antibacterial peptides with low MIC and low hemolytic activity.

Generally, synthetic AMPs have focused on variation of the natural peptide sequences or development of novel peptides from large synthetic combinatorial libraries, ${ }^{11}$ which represents a major advance in the discovery of new compounds for drug development. ${ }^{12-14}$ Furthermore, discrimination between eukaryotic and prokaryotic cell membranes ${ }^{15}$ provides a better understanding of the mechanisms underlying the lytic specificity of peptides. One important class of membrane-interacting AMPs assumes an amphipathic, $\alpha$-helical conformation that permits insertion of a well-defined hydrophobic sector into the lipid bilayer. ${ }^{16}$

Tossi et al. ${ }^{11}$ reported an alternative methodology for the design of $\alpha$-helical AMPs, which is based on the comparison of known

${ }^{1}$ Department of Biochemistry, Faculty of Science, Khon Kaen University, Khon Kaen, Thailand; 2Department of Bioscience, School of Agriculture, Tokai University, Kumamoto, Japan and ${ }^{3}$ Department of Social Sciences, Faculty of Humanities and Social Sciences, Khon Kaen University, Khon Kaen, Thailand 
sequences. The sequence templates were filled out with appropriate residues, so as to ensure a high helix-forming potential and to maintain the highest possible amphipathicity. Other potentially important features, such as length and cationicity were also considered. Two types of amino-acid side chains have important roles in antimicrobial activity of peptides, namely, (i) the cationic side chains arginine $(\mathrm{R})$, lysine $(\mathrm{K})$ and histidine $(\mathrm{H})$ mediate peptide interactions with negatively charged membranes or cell walls of bacteria, and (ii) bulky nonpolar side chains, for instance proline $(\mathrm{P})$, phenylalanine $(\mathrm{F})$, tryptophan $(\mathrm{W})$ and Trp show a distinct preference for the interfacial region of lipid bilayers. $^{17}$

Based on Leucrocin I sequence, NGVQPKY, the peptide, NY15, $\mathrm{N}^{1} \mathrm{~K}^{2} \mathrm{~K}^{3} \mathrm{~A}^{4} \mathrm{G}^{5} \mathrm{~L}^{6} \mathrm{~F}^{7} \mathrm{~V}^{8} \mathrm{~V}^{9} \mathrm{Q}^{10} \mathrm{~F}^{11} \mathrm{P}^{12} \mathrm{~K}^{13} \mathrm{~K}^{14} \mathrm{Y}^{15}$, was designed by using the Antimicrobial Peptide Database (APD: http://aps.unmc.edu/AP/ main.html). ${ }^{18}$ This web tool offers a research interface to select peptides with search criteria such as length, structure, hydrophobic percentage, net charge and the target organism and provides statistical information on peptide sequence, structure and function, average peptide length, average net charge per peptide and frequency of each amino acid. Hydrophobic amino acids $\left(\mathrm{A}^{4}, \mathrm{~L}^{6}, \mathrm{~F}^{7}, \mathrm{~V}^{8}, \mathrm{~F}^{11}\right)$ were added to the central part of Leucrocin I sequence to construct a hydrophobic rich domain. As we wished to increase the positive change in the peptides structure, the amino acids lysine $(\mathrm{K})$ were added to $\mathrm{N}$-terminus and $\mathrm{C}$-terminus (hydrophilic lysine domain) $\left(\mathrm{K}^{2}, \mathrm{~K}^{3}, \mathrm{~K}^{13}\right)$ of this sequence. In this study, we chose lysine $(\mathrm{K})$ as a positive charge in the peptide structure instead of arginine (R) because previous results ${ }^{19}$ have shown that arginine (R)-containing peptides cause relatively strong calcein leakage from zwitterionic 1-palmitoyl-2-oleoylphosphatidylcholine, eukaryotic mimic membrane, whereas lysine (K)-substituted analogues showed less membrane lytic activity. Therefore, the design of the NY15 structure is based on characteristics of naturally occurring AMPs: short, preferably cationic and with $>30 \%$ of hydrophobic residues. The synthesis of NY15 was made from all L-amino acids (L-NY15) and all D-amino acids (D-NY15). Further comparisons were made of efficacies and the killing mechanism of both enantiomers peptides. Here we report that both L- and D-NY15 appeared to be potent antibacterial peptides against Gram-positive and Gram-negative bacteria without any toxicity for mammalian cells at their bacteriolytic concentrations. We also found that the peptide made from all D-amino acids was more active than the corresponding L-enantiomer

\section{MATERIALS AND METHODS}

\section{Peptide design and synthesis}

The NY15 was constructed using Antimicrobial Peptide Database (APD: http://aps.unmc.edu/AP/ main.html) based on the Leucrocin I (NGVQPKY) sequence. The sequence of Leucrocin I was submitted to APD2: Antimicrobial Peptide Designer to improved antimicrobial property depends on length, structure, hydrophobic percentage and net charge. Hydrophobic amino acids $\left(\mathrm{A}^{4}, \mathrm{~L}^{6}, \mathrm{~F}^{7}, \mathrm{~V}^{8}, \mathrm{~F}^{11}\right)$ and positive change amino acids $\left(\mathrm{K}^{2}, \mathrm{~K}^{3}, \mathrm{~K}^{13}\right)$ were added to Leucrocin I sequence. NY15 (NKKAGLFVVQFPKKY) sequence was predicted antimicrobial potent by using APD2: Antimicrobial Peptide Calculator and Predictor. The prediction showed that this peptide form alpha helices and it may have at least three residues on the same hydrophobic surface, and may interact with membranes and has a chance to be an AMP.

Peptides were synthesized using solid-phase methodology with Fmocprotected amino acids (GL Biochem, Shanghai, China). Purification by preparative reversed phase-HPLC gave final products that were $>95 \%$ pure. Peptide structures were characterized by electrospray ionization-MS (Table 1)
Table 1 Sequences, masses, net positive charge and \% hydrophobicity of peptides

\begin{tabular}{|c|c|c|c|c|c|}
\hline \multirow[b]{2}{*}{ Peptide } & \multirow{2}{*}{$\begin{array}{l}\text { Amino-acid } \\
\text { sequence }\end{array}$} & \multicolumn{2}{|c|}{ Molecular mass (Da) } & \multirow{2}{*}{$\begin{array}{c}\text { Net } \\
\text { positive } \\
\text { charge }\end{array}$} & \multirow{2}{*}{$\begin{array}{l}\% \text { Hydro- } \\
\text { phobic }\end{array}$} \\
\hline & & Calculated ${ }^{a}$ & Measured $^{\mathrm{b}}$ & & \\
\hline Leucrocin I & NGVQPKY & 804.90 & 804.91 & 1 & 11 \\
\hline $\begin{array}{l}\text { NY15 } \\
\text { (L-and D-form) }\end{array}$ & NKKAGLFVVQFPKKY & 1767.15 & 1767.16 & 4 & 40 \\
\hline
\end{tabular}

a Mass of each peptide was determined by electrospray ionization (ESI)-MS.

bMass of each peptide was calculated by PeptideMass (http://web.expasy.org/peptide_mass/).

\section{CD spectroscopy}

The secondary structures of peptides were examined by CD spectroscopy. Each peptide was dissolved in $10 \mathrm{~mm}$ sodium phosphate buffer $\mathrm{pH} 7.2$ or $50 \% 2,2,2$ Trifluoroethanol (TFE) to a final concentration of $0.1 \mathrm{mg} \mathrm{ml}^{-1}$. The molar ellipticities of peptides were determined using a Jasco J-715 spectropolarimeter (Jasco, Easton, MD, USA). Each spectrum was the average of five scans over the range 190-260 $\mathrm{nm}$ using a quartz cell of $1 \mathrm{~mm}$ optical path length at room temperature..$^{20,21}$ The scanning speed was $20 \mathrm{~nm} \mathrm{~min}^{-1}$ at an interval of $0.1 \mathrm{~nm}$, 1 -s response time and $1.0 \mathrm{~nm}$ bandwidth. Before calculation of the final ellipticity, all spectra were smoothed and corrected for buffer blanks.

\section{Antibacterial activity}

Antibacterial activity against Bacillus sphaericus TISTR 678, Bacillus megaterium (clinical isolate), V. cholerae (clinical isolate), S. typhi (clinical isolate), S. typhi ATCC 5784 and Escherichia coli 0157:H7 was measured using liquid growth inhibition assays ${ }^{22}$ using a broad spectrum AMP Magainin2 as the positive control. Briefly, $10 \mu \mathrm{l}$ of peptide solution were incubated in microtiter plates with $100 \mu \mathrm{l}$ of a suspension of bacteria at a starting $\mathrm{OD}_{\text {of }} \mathrm{OD}_{600}=0.001$ in nutrient broth. Bacterial growth was assayed by measurement of OD at $A_{550}$ after 16- to 20 -h incubation at $37^{\circ} \mathrm{C}$. The MIC of each peptide was defined as the lowest peptide concentration that completely inhibited growth. ${ }^{23}$

\section{Enzymatic degradation}

The peptide (L-NY15 or D-NY15) was dissolved in $0.1 \mathrm{M}$ Tris-HCl, $\mathrm{pH} 8.0$ and digested with trypsin (1/50, w/w, TR-TPCK, Cooper Biomedical Co., Malvern, PA, USA) at $37^{\circ} \mathrm{C}$, for $20 \mathrm{~min}$. After the incubation, digested peptides were determined for the antibacterial activity against $V$. cholerae using liquid growth inhibition assay.

\section{Bactericidal activity}

The bactericidal activity of peptides was assayed against $V$. cholerae as described by Boman et al. ${ }^{24} \mathrm{~V}$. cholerae was grown in nutrient broth and harvested at the logarithmic phase of growth by centrifugation at $3000 \mathrm{~g}$ for $5 \mathrm{~min}$, washed three times with $10 \mathrm{~mm}$ sodium phosphate buffer $\mathrm{pH}$ 7.2. The bacterial cells were re-suspended with the same buffer to a final concentration of $1 \times 10^{8} \mathrm{CFU} \mathrm{ml}{ }^{-1}$. One hundred microliters of $V$. cholerae cells were mixed with peptides solution containing fivefold of MIC $(5 \times$ MIC $)$ value of each peptide, and incubated at $37^{\circ} \mathrm{C}$. Aliquots $(5 \mu \mathrm{l})$ were withdrawn at time intervals, adequately diluted, plated on a nutrient agar plate and then the colonies were counted after incubation overnight at $37^{\circ} \mathrm{C}$.

\section{Hemolytic activity}

The hemolytic activity of peptides was determined based on hemolysis of human red blood cells. The human red blood cells were centrifuged, washed three times with saline $(0.85 \% \mathrm{NaCl})$ and re-suspended to $2 \%(\mathrm{v} / \mathrm{v})$ in phosphate-buffered saline ( $35 \mathrm{~mm}$ phosphate, $\mathrm{pH} 7.0,150 \mathrm{~mm} \mathrm{NaCl})$. One hundred microliters of human red blood cells solution were incubated with $10 \mu \mathrm{l}$ of different peptide concentrations for $1 \mathrm{~h}$ at $37^{\circ} \mathrm{C}$. The samples were centrifuged for $5 \mathrm{~min}$ and hemolysis was determined by measuring the OD of the supernatant at $415 \mathrm{~nm}$. Zero hemolysis (blank) and 100\% hemolysis were 
determined in phosphate-buffered saline buffer and $0.1 \%$ Triton X-100, respectively.

\section{Cytotoxicity}

The colorimetric 3-(4 5-dimethylthiazol-2-yl)-2 5-diphenyltetrazolium bromide assay was used to determine the cytotoxicity of peptides on Vero cell. Briefly, $1 \times 10^{5}$ cells per well in Dulbecco's modified Eagle's medium-F12 medium supplemented with $10 \%$ fetal bovine serum were placed into 96 -well plates. After incubation for $24 \mathrm{~h}$ under a fully humidified atmosphere of $95 \%$ room air and $5 \% \mathrm{CO}_{2}$ at $37^{\circ} \mathrm{C}$, peptides were added to cell cultures at a final concentration of MIC and $5 \times$ MIC values. Toxicity was evaluated after $24 \mathrm{~h}$ of incubation by measuring the OD of the culture at $570 \mathrm{~nm}$ using 3-(4 5dimethylthiazol-2-yl)-2 5-diphenyltetrazolium bromide dye reduction assay based on conversion of the yellow tetrazolium salt 3-(4 5-dimethylthiazol-2yl)-2 5-diphenyltetrazolium bromide into purple formazan crystals by metabolically active cells.

\section{Outer membrane permeability}

The outer membrane assay was performed to determine the ability of peptides to permeabilize the bacterial outer membrane by measuring the uptake of the normally impermeable fluorophor 1-N-phenylnapthylamine (NPN). For assays, overnight cultures of $V$. cholerae were transferred to fresh nutrient broth medium and grown to $\mathrm{OD}_{600}$ values of $0.5-0.6$. Cells were harvested, washed with $5 \mathrm{~mm}$ HEPES buffer $\mathrm{pH} 7.24$ and resuspended in $5 \mathrm{~mm}$ KCN in HEPES buffer $\mathrm{pH} 7.24\left(\mathrm{OD}_{600}\right.$ around 0.5$)$. To $3 \mathrm{ml}$ of cells, $60 \mu \mathrm{l}$ of $500 \mu \mathrm{m}$ NPN was added, followed by the peptide samples after $30 \mathrm{~s}$. Excitation and emission wavelengths were set at 315 and $400 \mathrm{~nm}$, respectively. After the addition of peptides, the increase in fluorescence as a result of partitioning of NPN into the interior outer membrane was measured for $5 \mathrm{~min}$ by using a fluorescence spectrophotometer. Polymyxin B sulfate, an antibiotic that can alter bacterial outer membrane permeability, was used as a positive control.

\section{Inner membrane permeability}

Inner membrane permeability was determined by measuring SYTOX Green influx assay. The experiment was performed according to Li et al. ${ }^{25}$ with some modifications. $V$. cholerae cells were grown to mid logarithmic phase at $37^{\circ} \mathrm{C}$, washed two times and suspended in phosphate-buffered saline buffer $\left(1 \times 10^{8} \mathrm{cells} \mathrm{ml}^{-1}\right)$. Aliquots of $100 \mu \mathrm{l}$ of this cell suspension were deposited in each well of a standard 96-well plate. Ten microliters of the peptide solution (final concentration at MIC value) containing $5 \mu \mathrm{M}$ SYTOX Green was added to the wells. The time-dependent increase in fluorescence excited by binding of the cationic dye to intracellular DNA was monitored using a SpectraMax M5 fluorescence microplate reader (Sunnyvale, CA, USA). The excitation and emission wavelengths were 504 and $523 \mathrm{~nm}$, respectively.

\section{DNA-binding assay}

A gel retardation experiment was carried out to observe the influence of peptides on the migration of DNA in agarose gels. ${ }^{26}$ Bacterial DNA used for this test was $\lambda \mathrm{DNA} / E c \mathrm{RI}$ (Promega US G1721, Madison, WI, USA), which had been cut with restriction enzyme EcoRI into fragments sized 21.2, 7.4, 5.8, 5.6, 4.8 and $3.5 \mathrm{kbp}$. The DNA was mixed with $10 \mathrm{X}$ binding buffer consisting of $100 \mathrm{~mm}$ Tris, $200 \mathrm{~mm} \mathrm{KCl,} 10 \mathrm{~mm}$ EDTA, 10 mм DTT and 50\% (v/v) glycerol, water and peptides at increasing peptide to DNA ratios. The solutions were incubated at room temperature for an hour. To separate the DNA fragments, $2 \mu \mathrm{l}$ of loading buffer was added before the samples were loaded onto a $0.75 \%$ agarose/Tris-acetate-EDTA gel and run at $70 \mathrm{~mA}$ for $1.5 \mathrm{~h}$. The gel was then stained with ethidium bromide and photographed using the Gel Doc XR System (Bio-Rad Laboratories, Hercules, CA, USA). Buforin II, an AMP that kills bacteria by entering cells and binding nucleic acids, was used as a positive control.

\section{Scanning electron microscopy (SEM)}

SEM was performed according to Lau et al. ${ }^{27}$ with slight modifications. $V$. cholerae was grown in nutrient broth and harvested at the logarithmic phase of growth by centrifugation at $3000 \mathrm{~g}$ for $5 \mathrm{~min}$. The bacterial cells were then washed twice with $10 \mathrm{~mm}$ sodium phosphate buffer $\mathrm{pH} 7.2$ and re-suspended with the same buffer to a final concentration of $1 \times 10^{8} \mathrm{CFU} \mathrm{ml}^{-1}\left(\mathrm{OD}_{600}=\right.$ 0.1 ). Aliquots of suspensions of $V$. cholerae were individually incubated with MIC and $5 \times$ MIC of peptides at $37^{\circ} \mathrm{C}$ for $1 \mathrm{~h}$. The $100 \mu \mathrm{l}$ solutions of the bacterial cells were carefully pipetted and applied to a $0.2 \mu \mathrm{m}$ cellulose acetate membrane filter (Sartorius AG, Göttingen, Germany) for 30 min whereupon cells were fixed with $300 \mu \mathrm{l}$ of $2.5 \%$ (v/v) glutaraldehyde (Sigma, St Louis, MO, USA) for $1 \mathrm{~h}$. The fixed material was dehydrated by rinsing (for $15 \mathrm{~min}$ ) repeatedly with a series of ethanol solutions containing 30,50, 70, 90 and finally $100 \%$ ethanol. Dry materials were coated with a sputter coater (SC7620, Polaron, Hertfordshire, UK) with gold palladium and examined by SEM (LEO1450VP, LEO Electron Microscopy, Cambridge, UK) operating at $12-20 \mathrm{kV}$.

\section{Transmission electron microscopy}

Transmission electron microscopy was performed according to Hao et al. ${ }^{28}$ with slight modifications. $V$. cholerae was grown in nutrient broth and harvested at the logarithmic phase of growth by centrifugation at $3000 \mathrm{~g}$ for $5 \mathrm{~min}$. The bacterial cells were washed twice with $10 \mathrm{~mm}$ sodium phosphate buffer pH 7.2 and re-suspended with the same buffer to a final concentration of $1 \times 10^{8} \mathrm{CFU} \mathrm{ml}{ }^{-1}$. The bacterial cells were treated with peptides at MIC and $5 \times \mathrm{MIC}$, for $1 \mathrm{~h}$ at $37^{\circ} \mathrm{C}$. After treatment, the bacterial pellets were fixed with fixative reagent (5\% glutaraldehyde and 10\% formaldehyde in distilled water) for $10 \mathrm{~min}$. Ten microliters of bacterial cells were dropped on copper grids and then washed with distilled water. The copper grids were dried in a desiccator. Microscopy was performed with a Tecnai 20 Twin microscope (Hillsboro, OR, USA) under standard operating conditions.

\section{RESULTS AND DISCUSSION}

\section{Structural analysis of peptides by CD measurements}

The secondary structure of linear antibacterial peptides in lipid membranes rather than in phosphate buffer should correlate well with the activity. ${ }^{28}$ To investigate the secondary structure of the peptides, CD spectra of Leucrocin I, L- and D-NY15 peptides were measured in phosphate buffer and membrane mimic conditions in the presence of 50\% TFE solution. Structural analysis showed that the CD spectra of D-NY15 in an aqueous solution and 50\% TFE are a mirror image of that of L-NY15. All peptides showed a random coil structure in an aqueous solution, whereas secondary structures of Land D-NY15 tend to be more ordered when they interacted with bacterial mimic membrane (50\% TFE; Figure 1). However, they did

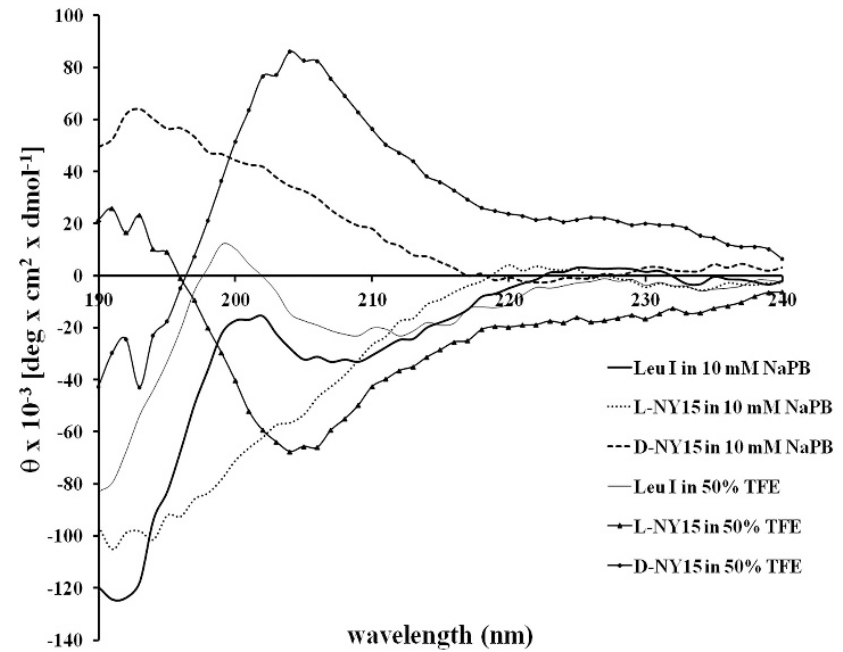

Figure 1 CD spectrum of Leucrocin I (Leu I), L-NY15 and D-NY15 dissolved in $10 \mathrm{~mm}$ sodium phosphate buffer (NaPB) and a membrane mimic condition in the presence of $50 \%$ TFE solution. 
not have their maximum $\alpha$-helical content when interacted with bacterial membranes. The deconvolution of spectrum was determined by using K2D2 program. ${ }^{29}$ The results showed that the $\alpha$-helical content in Leucrocin I and NY15 peptides (in 50\% TFE) were 8.2\% and $87.6 \%$, respectively (Table 2). These results implied that NY15 adopts amphipathic $\alpha$-helical structure on the membrane. This characteristic is similar to linear AMPs, such as the silk moth's cecropin and the African clawed frog's magainin, which adopt this organization only when they enter a membrane, whereupon they assume an amphipathic $\alpha$-helical secondary structure. ${ }^{30}$

\section{Antibacterial activity assays}

The MICs of synthetic peptides obtained for B. sphaericus TISTR 678, B. megaterium (clinical isolate), V. cholerae (clinical isolate), S. typhi (clinical isolate), S. typhi ATCC 5784 and E. coli 0157:H7 compared with Magainin2 are shown in Table 3. The results show that synthetic Leucrocin I showed less activity than L- and D-NY15. A comparison of antibacterial peptides MICs indicates that the lowest MIC was found in NY15 made from D-amino acids. This result is similar to the antibacterial effects of lactoferricin $\mathrm{B},{ }^{31}$ the lactoferricin $\mathrm{B}$ peptide made of all D-amino acids was more active than the corresponding L-enantiomer. However, Wade et al. ${ }^{32}$ have indicated that enantiomers of AMPs are equally active. Peptides with equally active enantiomers, cannot have stereo-specific targets like protein receptors. Alternatively, the results might indicate that the L-enantiomer is being enzymatically degraded before reaching the target, as most proteolytic enzymes have greatly reduced activity against $\mathrm{D}$-aminoacid residues. ${ }^{31}$ To test this hypothesis, L-NY15 and D-NY15 were digested with trypsin and subsequently evaluated for the antibacterial activity against $V$. cholerae using liquid growth inhibition assays. The results showed that L-NY15 was very sensitive to trypsin degradation, leading to lower

Table 2 The percentage content in $\alpha$-helix and $\beta$-sheet of a peptide

\begin{tabular}{lcccccc}
\hline & \multirow{2}{*}{ \% Of content in } & 10 mm NaPB & & \multicolumn{2}{c}{$\%$ Of content in } & $50 \%$ TFE \\
\cline { 2 - 3 } Peptide & $\alpha$-Helix & $\beta$-Sheet & & $\alpha$-Helix & $\beta$-Sheet \\
\hline Leucrocin I & 8.0 & 22.1 & & 8.2 & 24.1 \\
NY15 & 8.0 & 22.1 & & 87.6 & 0.5 \\
\hline
\end{tabular}

Abbreviation: NaPB, sodium phosphate buffer.

aThe percentage content in alpha helix and beta sheet of a peptide in $10 \mathrm{~mm} \mathrm{NaPB}$ or $50 \%$ TFE was estimated by the K2D2 method from website: http://www.ogic.ca/projects/k2d2/, the estimated maximum error was $>0.32$.

Table 3 Antibacterial activities of peptides against Gram-positive and Gram-negative bacteria

\begin{tabular}{|c|c|c|c|c|c|c|}
\hline \multirow[b]{4}{*}{ Peptide } & \multicolumn{6}{|c|}{ MIC ( $\mu \mathrm{M})$} \\
\hline & B. megaterium & & V. cholerae & & S. typhi & S. typhi \\
\hline & (clinical & B. sphaericus & (clinical & E. coli & (clinical & ATCC \\
\hline & isolate) & TISTR 678 & isolate) & 0157:H7 & isolate) & 5784 \\
\hline Leucrocin I & $>64$ & $>64$ & $>64$ & $>64$ & $>64$ & $>64$ \\
\hline L-NY15a & 28.3 & 64 & 52 & $>64$ & $>64$ & $>64$ \\
\hline D-NY15 & 5.1 & 15.4 & 15.4 & 41.2 & 52 & 52 \\
\hline Magainin $2^{c}$ & 3.7 & 18.4 & 7.4 & 36.9 & 11.1 & 14.7 \\
\hline
\end{tabular}

aThe peptide made from all L-amino acids.

'The peptide made from all D-amino acids.

'Used as the positive control. antimicrobial activity (14\% inhibition). In contrast, all D-NY15 were very resistant, after trypsin treatment they still rendered relatively high activity (84\% inhibition; Supplementary Figure S1).

\section{Bactericidal activity}

The bactericidal activity of $\mathrm{L}^{-}$and $\mathrm{D}-\mathrm{NY} 15$ was assayed against $V$. cholerae, and the same experiment was performed with Magainin2. The results showed that when $V$. cholerae cells were treated with $5 \times$ MIC that is, $260.1 \mu \mathrm{M}$ of $\mathrm{L}-\mathrm{NY} 15$ and $77 \mu \mathrm{M}$ of $\mathrm{D}-\mathrm{NY} 15$, the number of viable cells decreased by seven orders of magnitude (Figure 2). The results indicate that L- and D-NY15 showed rapid killing of the bacteria. However, when the cells were treated with $5 \times$ MIC of Magainin2 the number of viable cells decreased by eight orders of magnitude.

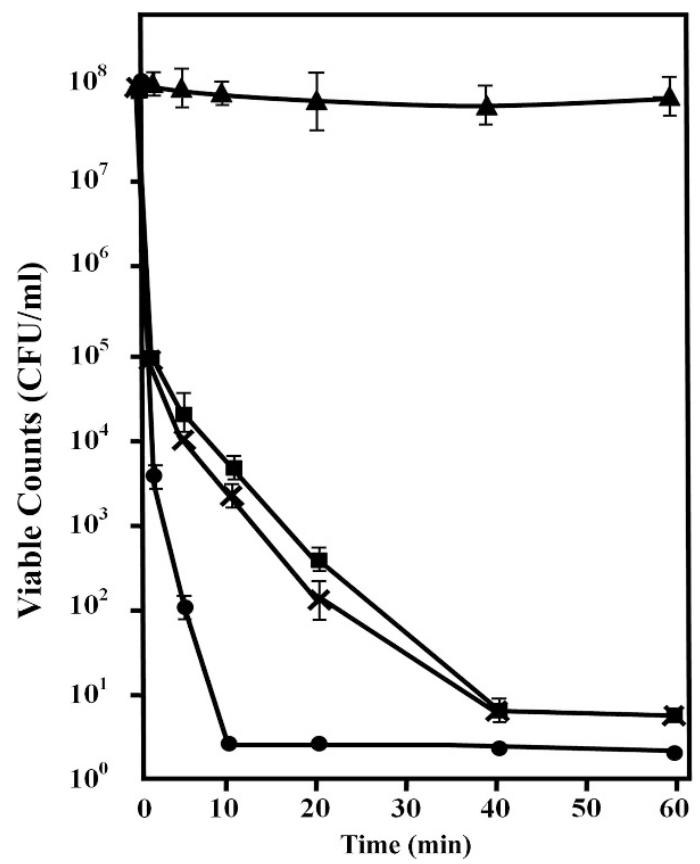

Figure 2 The bactericidal activity of NY15 peptides against Vibrio cholerae; $\boldsymbol{\Delta}=0.01 \%$ acetic acid, $\boldsymbol{\square}=\mathrm{L}-\mathrm{NY} 15$ (L-form) $260.05 \mu \mathrm{M}, \quad \times=\mathrm{D}-\mathrm{NY} 15$ (D-form) $77.15 \mu \mathrm{m}, \mathbf{O}=$ Magainin2 $36.85 \mu \mathrm{m}$.

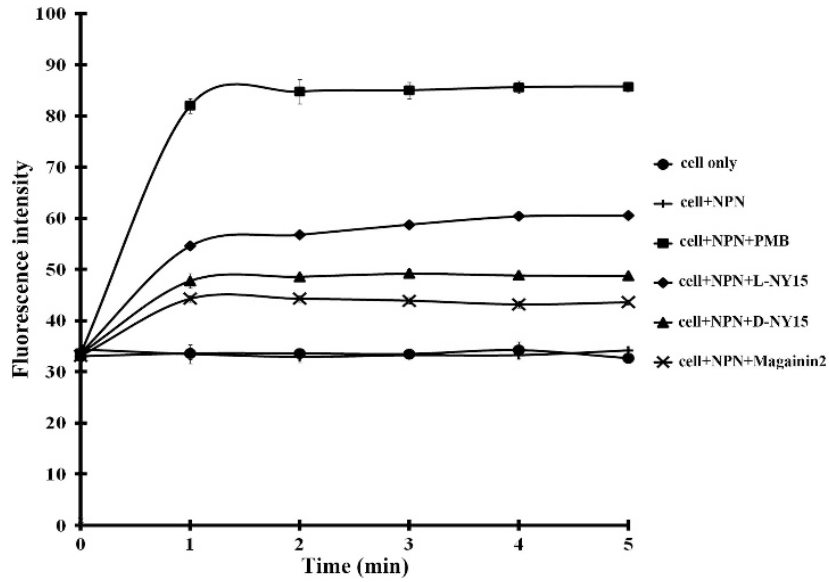

Figure 3 1-N-phenylnapthylamine (NPN) uptake assay of peptides using Vibrio cholerae (clinical isolated). 


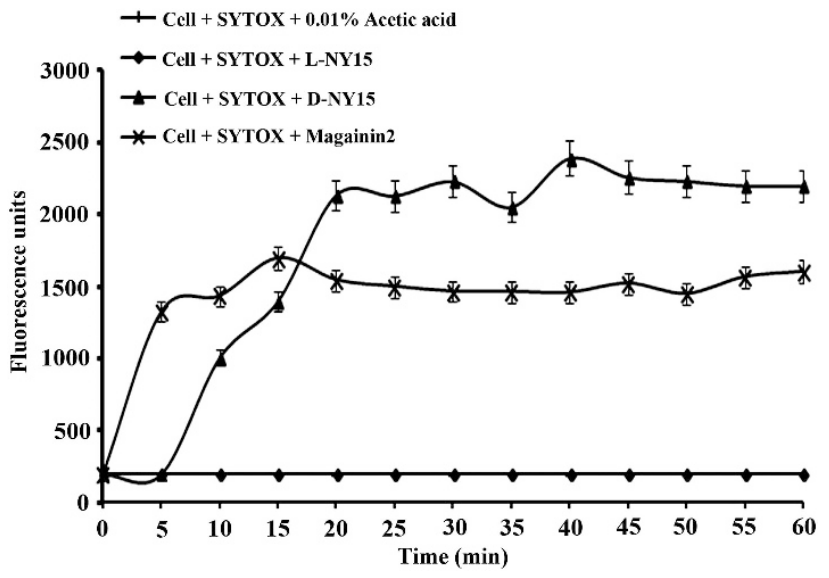

Figure 4 Cytoplasmic membrane permeabilization of Vibrio cholerae monitored by entry of the DNA fluorescent probe SYTOX Green at $\lambda_{\text {excitation }}=504 \mathrm{~nm}$ and $\lambda_{\text {emission }}=523 \mathrm{~nm}$.
Hemolytic activity and cytotoxicity assay

The peptides were tested for hemolytic activity against human red blood cells and cytotoxicity against Vero cells at MIC and $5 \times$ MIC values. No significant hemolytic activity and cytotoxic activity were observed. These results indicate that L- and D-NY15 may be a good candidate for antimicrobial drug development.

\section{Outer membrane permeability}

Gram-negative bacteria have two envelope membranes, an outer and an inner membrane. In the case of Gram-negative bacteria, the outer membrane has a role as a drug barrier. ${ }^{14}$ To assay the mode of action of the antibacterial peptides on bacterial outer membrane, the NPN, a hydrophobic fluorescence probe, was used. ${ }^{33,34}$ Normally, NPN fluoresces weakly in an aqueous environment and strongly when it enters a hydrophobic environment such as the interior of a membrane. ${ }^{34}$ The addition of $\mathrm{L}^{-}$and D-NY15 to $V$. cholerae suspensions in the presence of NPN caused increase in the fluorescence intensity from $\sim 33$ to $\sim 50$ within $1 \mathrm{~min}$ when
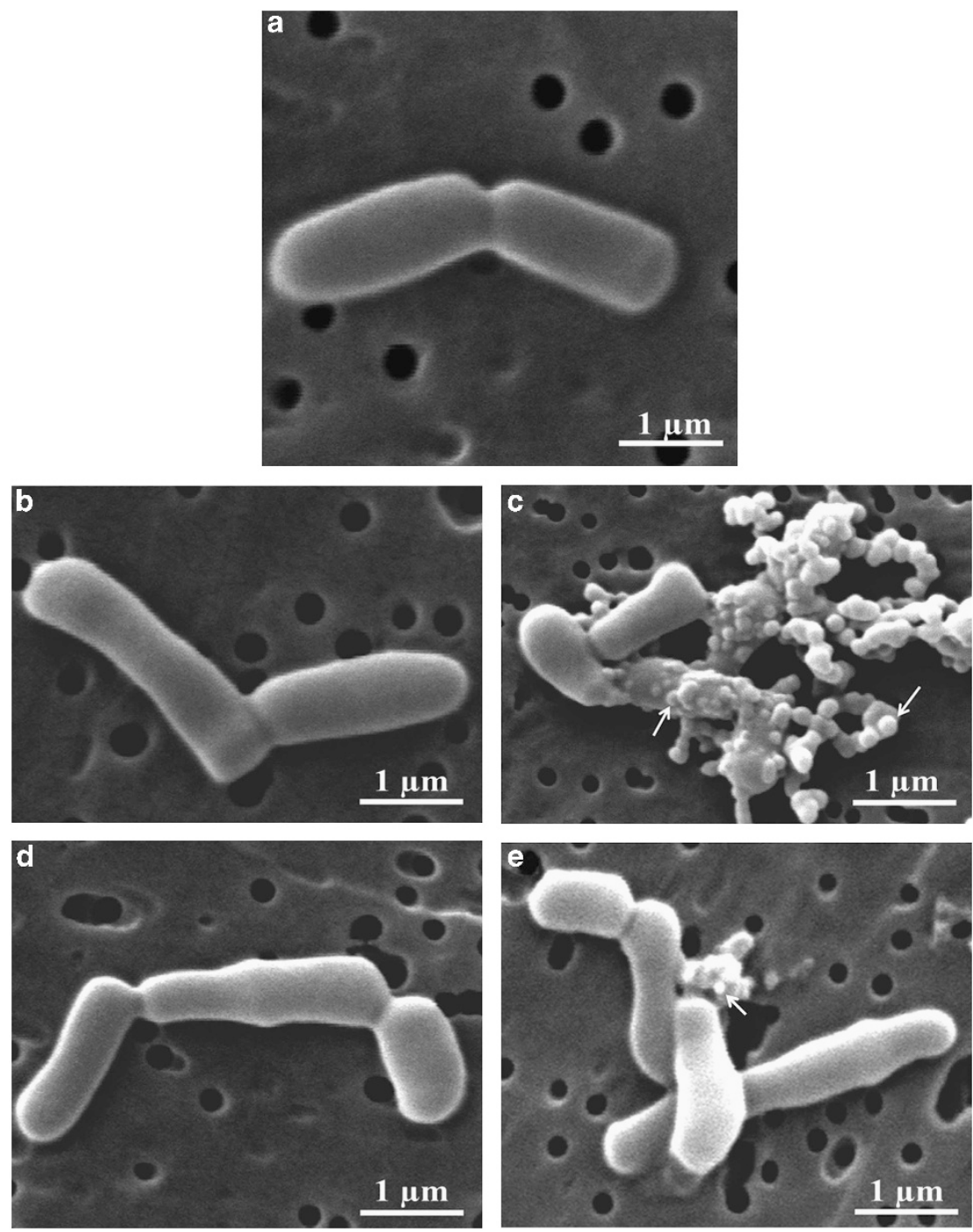

Figure 5 Scanning electron micrographs of Vibrio cholerae treated with peptides. (a) Control bacteria after treatment with $0.01 \%$ acetic acid for $1 \mathrm{~h}$. (b, c) Bacteria after treatment with L-NY15 at MIC and $5 \times$ MIC for $1 \mathrm{~h}$. (d, e) Bacteria after treatment with D-NY15 at MIC and $5 \times$ MIC for $1 \mathrm{~h}$. 

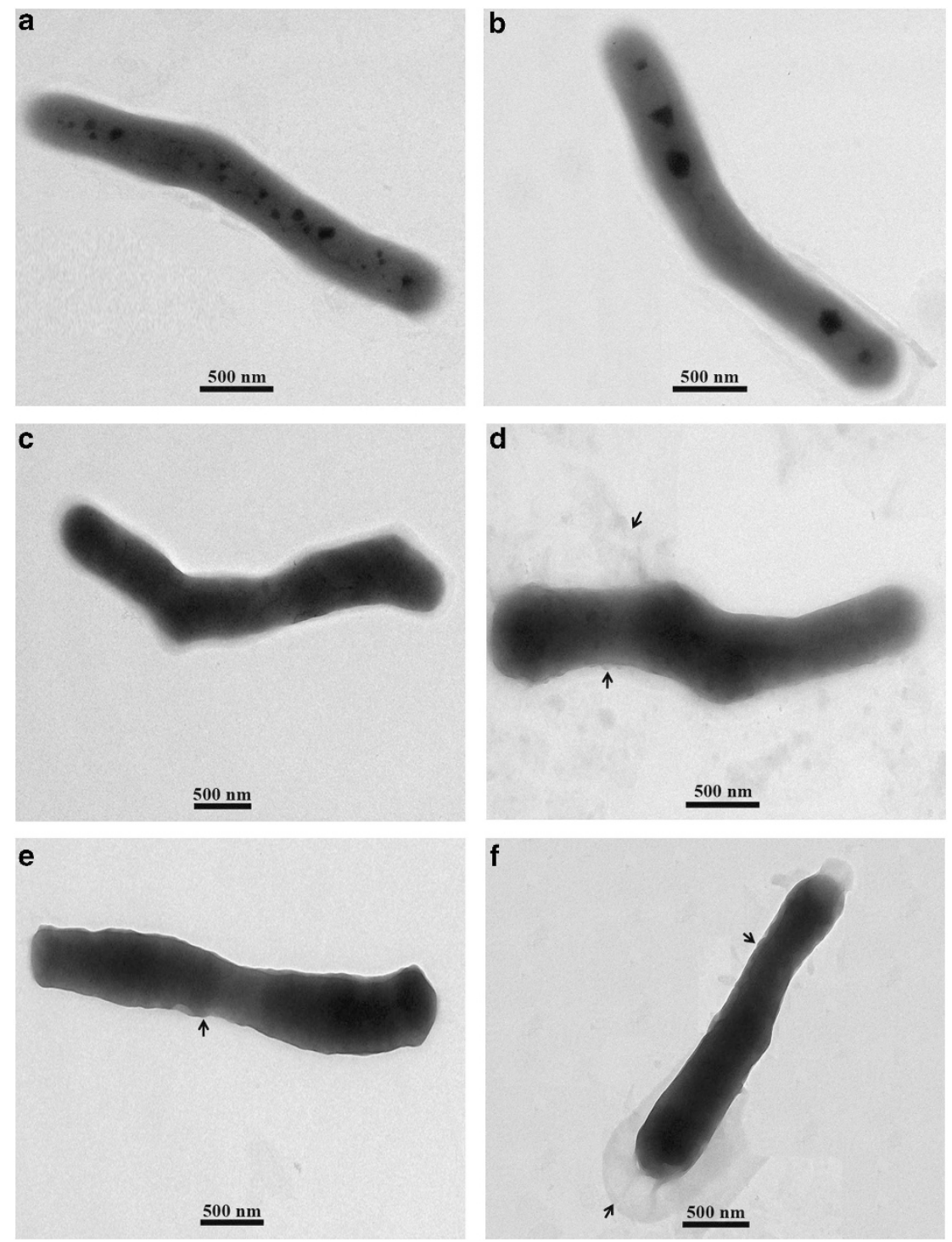

Figure 6 Transmission electron micrographs of Vibrio cholerae treated with peptides. (a, b) Control bacteria after treatment with $0.01 \%$ acetic acid only $1 \mathrm{~h}$. (c, d) Bacteria after treatment with L-NY15 at MIC and $5 \times$ MIC for $1 \mathrm{~h}$. (e, f) Bacteria after treatment with D-NY15 at MIC and $5 \times$ MIC for $1 \mathrm{~h}$. See the Results and Discussion section for other experimental details and descriptions of the images.

compared with cells in buffer only and cells with NPN only that acted as the negative control (Figure 3). After $1 \mathrm{~min}$, all of the tested samples except the negative control seemed to stable intensity of fluorescence until the end of the experiment ( $5 \mathrm{~min})$. A higher increase in fluorescence of $V$. cholerae treated with L-NY15 peptide was observed when compared with D-NY15 peptide. However, they were lower than the fluorescence of $V$. cholerae treated with the positive control, polymyxin B sulfate. Therefore, our results indicated that both L- and D-NY15 peptides have permeabilized the outer membrane of the intact cells similarly to polymyxin B sulfate and other cationic AMPs including SMAP-29, ${ }^{35}$ Indolicidin $^{33}$ and Temporin-L. ${ }^{36}$

\section{Inner membrane permeability}

We subsequently evaluated the ability of synthetic L- and D-NY15 to permeate the $V$. cholerae inner membrane. SYTOX Green can penetrate cells with a compromised plasma membrane but will not cross the membranes of live cells. ${ }^{37}$ Fluorescence of SYTOX Green is enhanced when bound to intracellular nucleic acids. SYTOX Green was used to analyze the effect of L- and D-NY15 on membranes of living $V$. cholerae cells. The addition of D-NY15 at MIC to $V$. cholerae suspensions in the presence of SYTOX Green caused increased fluorescence after $5 \mathrm{~min}$ (Figure 4) when compared with cells with $0.01 \%$ acetic acid that acted as the negative control. However, L-NY15 did not cause an increase in fluorescence. This suggested that the influx of SYTOX Green into $V$. cholerae cells increased over time with the increase in plasma membrane permeability induced by D-NY15. It might be L-enantiomer is being enzymatically degraded before reaching the target, as most proteolytic enzymes have greatly reduced activity against D-aminoacid residues. ${ }^{31}$ Magainin2, which kills bacteria by targeting membranes and forming a pore, was used as a positive control. Compared with D-NY15, Magainin2 induced a rapid fluorescence increase and quickly reached a maximum fluorescence state after $17 \mathrm{~min}$, however, D-NY15 showed an increase in fluorescence intensity, which was greater than that by Magainin2. The SYTOX 
Green influx analysis demonstrated that only D-NY15 (final concentration at MIC value) could increase living $V$. cholerae cell plasma membrane permeability.

\section{DNA-binding assay}

However, it has been reported that some cationic AMPs, such as Buforin II are able to transverse the cytoplasmic membrane and enter the cytoplasm where they can act on polyanionic molecules, such as DNA. ${ }^{38,39}$ Therefore, a DNA gel electrophoresis separation was carried out to determine whether L- and D-NY15 were able to interact with bacterial DNA. Peptides that are able to bind to $\lambda$ DNA will inhibit the migration of the DNA on the gel. When the peptides bind to DNA, they formed larger molecules, hence blocking their migration through the gel. ${ }^{40}$ We found that both L- and D-NY15 peptides could not inhibit the migration of the DNA on the gel at various weight ratios of peptides to DNA (0.5:1, 1:1, 2:1 and 4:1; Supplementary Figure S2). Buforin II, which was used as positive control, was effective in binding to DNA with all DNA fragments bound at a DNA: peptide ratio of 1:4. Some AMPs, such as Magainin2, require high concentrations to bind to DNA and RNA. ${ }^{38}$ As the direct killing mechanism of Magainin2 is to kill bacteria by targeting membranes and forming a pore, the result is leakage of small cellular molecules. From this result, the direct targeting site of both L- and D-NY15 action may be the cell membrane.

\section{Scanning electron microscopy}

SEM was chosen to measure the effects of both L- and D-NY15 peptides on the cell membranes of $V$. cholerae. The results show that untreated bacteria displayed a smooth bright surface with no apparent cellular debris (Figure 5a). Obvious abnormality of cell membrane was observed in cells treated with $5 \times$ MIC of L- and D-NY15 peptides. The cell surfaces of $V$. cholerae showed blebs and then a collapsed cell structure (Figures $5 \mathrm{c}$ and e). The SEMs results at $5 \times$ MIC clearly demonstrate that the bacterial cells are drastically physical damaged.

\section{Transmission electron microscopy}

Owing to $V$. cholerae is a Gram-negative bacterium; Gram-negative bacteria cell walls are more complex than Gram-positive cell walls. Structurally, a Gram-negative cell wall contains two layers external to the cytoplasmic membrane and some bacteria (Gram-positive or Gram-negative) are closely surrounded by loose polysaccharide or protein layers called capsules. Therefore, transmission electron microscopy observations of cells have been used to reveal the presence of capsule on $V$. cholerae and to observe the bacterial membrane. The bacteria were treated with MIC and $5 \times$ MIC of L- and D-NY15 for $1 \mathrm{~h}$ before fixing. These electron micrographs showed that the untreated cells exhibited normal, smooth surfaces as shown by visualization of the capsule and the capsular material cells of $V$. cholerae (black spot on the cell in Figures $6 \mathrm{a}$ and b). In contrast, peptide-exposed cells exhibited a wide range of significant abnormalities (Figures $6 \mathrm{c}-\mathrm{f}$ ). The peptide-exposed cells at MIC value were found to have a disorder of capsular materials (Figures $6 \mathrm{c}$ and e). Moreover, the cell membrane of $V$. cholerae treated with D-NY15 at $5 \times$ MIC value showed deep roughening. When the concentration of peptides was increased to $5 \times$ MIC value, a membrane permeabilizing effect became evident, releasing capsular material surrounding cells and some apparent leakage of cytoplasmic components (Figures $6 \mathrm{~d}$ and $\mathrm{f}$ ). Patrzykat et al. $^{41}$ have shown similar concentration-dependent behavior with some derivatives of pleurocidin, an AMP isolated from winter flounder. At the MIC concentration, these peptides had little capacity to damage the cell membranes of E. coli, whereas, at 10-fold their MIC value, all these peptides permeabilized the E. coli cell membranes. These results indicate that L- and D-NY15 have active target sites at the cell surface.

In summary, we report the design, synthesis and antibacterial activity of novel antibacterial peptides L- and D-NY15. The peptide made from all D-amino acids was more active than the corresponding L-enantiomer. We presume that both L- and D-NY15 kill bacteria by perturbing the permeability of the bacterial cell membrane. The cytotoxicity assays revealed that both L- and D-NY15 are non-toxic to mammalian cells at bacteriolytic concentrations.

\section{ACKNOWLEDGEMENTS}

This work was financially supported by a grant funded under the program Strategic Scholarships for Frontier Research Network for the Joint PhD Program Thai Doctoral Degree from the Office of the Higher Education Commission, Thailand, Thailand Research Fund and the Protein and Proteomics Research Center for Commercial and Industrial Purposes (ProCCI) funded by Khon Kaen University. We wish to acknowledge the support of the Khon Kaen University Publication Clinic, Research and Technology Transfer Affairs, Khon Kaen University, for their assistance.

1 Reddy, K. V. R., Yedery, R. D. \& Aranha, C. Antimicrobial peptides: premises and promises. Int. J. Antimicrob. Agents 24, 536-547 (2004).

2 Hancock, R. E. \& Patrzykat, A. Clinical development of cationic antimicrobial peptides: from natural to novel antibiotics. Curr. Drug Targets Infect. Dis. 2, 79-83 (2002)

3 Jenssen, H., Hamill, P. \& Hancock, R. E. Peptide antimicrobial agents. Clin. Microbiol. Rev. 19, 491-511 (2006).

4 Scott, M. G. \& Hancock, R. E. Cationic antimicrobial peptides and their multifunctional role in the immune system. Crit. Rev. Immunol. 20, 407-431 (2000).

5 Hancock, R. E. Cationic peptides: effectors in innate immunity and novel antimicrobials. Lancet. Infect. Dis. 1, 156-164 (2001).

6 Yeaman, M. R. \& Yount, N. Y. Mechanisms of antimicrobial peptide action and resistance. Pharmacol. Rev. 55, 27-55 (2003).

7 Dathe, M. \& Wieprecht, T. Structural features of helical antimicrobial peptides: their potential to modulate activity on model membranes and biological cells. Biochim. Biophys. Acta Biomembr. 1462, 71-87 (1999).

8 Brogden, K. A. Antimicrobial peptides: pore formers or metabolic inhibitors in bacteria. Nat. Rev. Microbiol. 3, 238-250 (2005).

9 Tossi, A., Sandri, L. \& Giangaspero, A. Amphipathic, alpha-helical antimicrobial peptides. Biopolymers 55, 4-30 (2000).

10 Pata, S. et al. Characterization of the novel antibacterial peptide Leucrocin from crocodile (Crocodylus siamensis) white blood cell extracts. Dev. Comp. Immunol. 35, 545-553 (2011).

11 Tossi, A., Tarantino, C. \& Romeo, D. Design of synthetic antimicrobial peptides based on sequence analogy and amphipathicity. Eur. J. Biochem. 250, 549-558 (1997).

12 Blondelle, S. E. Synthetic combinatorial libraries: novel discovery strategy for identification of antimicrobial agents. Antimicrob. Agents Chemother 40, 1067-1071 (1996).

13 Blondelle, S. E., Takahashi, E., Dinh, K. T. \& Houghten, R. A. The antimicrobial activity of hexapeptides derived from synthetic combinatorial libraries. J. Appl. Microbiol. 78, 39-46 (1995).

14 Hong, S. Y. et al. Identification and characterization of novel antimicrobial decapeptides generated by combinatorial chemistry. Antimicrob. Agents Chemother 42, 2534-2541 (1998).

15 Blondelle, S. E. \& Lohner, K. Combinatorial libraries: a tool to design antimicrobial and antifungal peptide analogues having lytic specificities for structure-activity relationship studies. Biopolymers 55, 74-87 (2000).

16 Zelezetsky, I. \& Tossi, A. Alpha-helical antimicrobial peptides-using a sequence template to guide structure-activity relationship studies. Biochim. Biophy. Acta Biomembr. 1758, 1436-14492006.

17 Chan, D. I., Prenner, E. J. \& Vogel, H. J. Tryptophan- and arginine-rich antimicrobial peptides: structures and mechanisms of action. Biochim. Biophy. Acta Biomembr. 1758, 1184-1202 2006.

18 Wang, Z. \& Wang, G. APD: the antimicrobial peptide database. Nucleic Acids Res. 32 590-592 (2004).

19 Yang, S.-T. et al. Selective cytotoxicity following Arg-to-Lys substitution in tritrpticin adopting a unique amphipathic turn structure. FEBS Lett. 540, 229-233 (2003).

$20 \mathrm{Ahn}, \mathrm{H}$. .s. et al. Design and synthesis of novel antimicrobial peptides on the basis of alpha helical domain of Tenecin 1 , an insect defensin protein, and structure-activity relationship study. Peptides 27, 640-648 (2006)

21 Chou, H.-T. et al. Design and synthesis of cationic antimicrobial peptides with improved activity and selectivity against Vibrio spp. Int. J. Antimicrob. Agents 32, 130-138 (2008). 
22 Duval, E., Zatylny, C., Laurencin, M., Baudy-Floc'h, M. \& Henry, J. KKKKPLFGLFFGLF: a cationic peptide designed to exert antibacterial activity. Peptides 30, 1608-1612 (2009).

23 Yang, S.-T., Shin, S. Y., Hahm, K.-S. \& Kim, J. I. Design of perfectly symmetric Trp-rich peptides with potent and broad-spectrum antimicrobial activities. Int. J. Antimicrob. Agents 27, 325-330 (2006).

24 Boman, H. G., Agerberth, B. \& Boman, A. Mechanisms of action on Escherichia coli of cecropin P1 and PR-39, two antibacterial peptides from pig intestine. Infect. Immun. 61, 2978-2984 (1993).

$25 \mathrm{Li}$, L., Shi, Y., Su, G. \& Le, G. Selectivity for and destruction of Salmonella typhimurium via a membrane damage mechanism of a cell-penetrating peptide ppTG20 analogue. Int. J. Antimicrob. Agents 40, 337-343 (2012).

26 Park, C. B., Kim, H. S. \& Kim, S. C. Mechanism of action of the antimicrobial peptide Buforin II: Buforin II kills microorganisms by penetrating the cell membrane and inhibiting cellular functions. Biochem. Biophys. Res. Commun. 244, 253-257 (1998).

27 Lau, S. K. P. et al. Eggerthella hongkongensis sp. nov. and eggerthella sinensis sp. nov. two novel Eggerthella species, account for half of the cases of Eggerthella bacteremia. Diagn. Microbiol. Infect. Dis 49, 255-263 (2004).

28 Hao, G., Shi, Y.-H., Tang, Y.-L. \& Le, G.-W. The membrane action mechanism of analogs of the antimicrobial peptide Buforin 2. Peptides 30, 1421-1427 (2009).

29 Lung, F.-D. T. et al. Discovery of potent antimicrobial peptide analogs of Ixosin-B. Bioorg. Med. Chem. Lett. 22, 4185-4188 (2012).

30 Zasloff, M. Antimicrobial peptides of multicellular organisms. Nature 415, 389-395 (2002).

31 Vorland, L. H. et al. Antibacterial effects of lactoferricin B. Scand. J. Infect. Dis. 31, 179-184 (1999).
32 Wade, D. et al. All-D amino acid-containing channel-forming antibiotic peptides. Proc Natl Acad. Sci. USA 87, 4761-4765 (1999).

33 Falla, T. J., Karunaratne, D. N. \& Hancock, R. E. W. Mode of action of the antimicrobial peptide indolicidin. J. Biol. Chem. 271, 19298-19303 (1996).

34 Loh, B., Grant, C. \& Hancock, R. E. W. Use of the fluorescent probe 1-Nphenylnaphthylamine to study the interactions of aminoglycoside antibiotics with the outer membrane of Pseudomonas aeruginosa. Antimicrob. Agents Chemother. 26, 546-551 (1984).

$35 \mathrm{Kalfa}$, V. C. et al. Congeners of SMAP29 kill ovine pathogens and induce ultrastructural damage in bacterial cells. Antimicrob. Agents Chemother. 45, 3256-3261 (2001).

36 Mangoni, M. L. et al. Effects of the antimicrobial peptide temporin $\mathrm{L}$ on cell morphology, membrane permeability and viability of Escherichia coli. Biochem. J. 380, 859-865 (2004).

37 Bourbon, C. et al. Use of a real-time polymerase chain reaction thermocycler to study bacterial cell permeabilization by antimicrobial peptides. Anal. Biochem. $\mathbf{3 8 1}$ 279-281 (2008)

38 Park, S.-C. et al. Amphipathic alpha-helical peptide, HP (2-20), and its analogues derived from Helicobacter pylori: pore formation mechanism in various lipid compositions. Biochim. Biophys. Acta Biomembr. 1778, 229-241 (2008).

39 Powers, J. P. \& Hancock, R. E. The relationship between peptide structure and antibacterial activity. Peptides 24, 1681-1691 (2003).

40 Sugiarto, H. \& Yu, P.-L. Mechanisms of action ofostrich $\beta$-defensins against Escherichia coli. FEMS Microbiol. Lett. 270, 195-200 (2007).

41 Patrzykat, A., Friedrich, C. L., Zhang, L., Mendoza, V. \& Hancock, R. E. W. Sublethal concentrations of pleurocidin-derived antimicrobial peptides inhibit macromolecular synthesis in Escherichia coli. Antimicrob. Agents Chemother. 46, 605-614 (2002).

Supplementary Information accompanies the paper on The Journal of Antibiotics website (http://www.nature.com/ja) 